\title{
Pemberitaan Aksi Gerakan Tagar 2019 Ganti Presiden Analysis Framing Robert N. Entman di Mediaindonesia.com Periode September 2018- Januari 2019
}

\author{
Diah Agung Esfandari, Muhammad Izzuddin Alqosam
}

\author{
Program Studi S1 Ilmu Komunikasi \\ Fakultas Komunikasi dan Bisnis, Universitas Telkom \\ Jl. Telekomunikasi Terusan Buah Batu, Bandung, Jawa Barat 40257, Indonesia \\ Email: esfandari@gmail.com ; moch.izzuddin@gmail.com
}

Abstract

The Internet and Media are the two things that make it easy for people to get and produce information. With the presence of the Internet and the media, making media companies take advantage of their presence in producing and disseminating information, like mediaindonesia.com. The purpose of this study was to find out how Media Indonesia framed the news about hashtag movement \#2019gantipresiden period September 2018-January 2019. This study used Robert N. framing analysis with qualitative research methods and constructivism paradigms. The results of this study indicate that Mediaindonesia.com has a view that tends to be neutral and objective. The information shown in this study is that the value carried in the news about hashtag movement \#2019gantipresiden that raises a split in the community that has different supporters in the 2019 election competition. \#2019gantipresiden also brings bad value to the current leader, because of name and news which was highlighted by the action was leaning towards an attempt to overthrow the President's leadership

Keywords: Framing Analysis, Robert N. Entman, \#2019gantipresiden, Online Media

\begin{abstract}
Abstrak
Internet dan media merupakan kedua hal yang memberikan kemudahan bagi masyarakat dalam mendapatkan dan memproduksi informasi. Dengan adanya kehadiran Internet dan media, membuat perusahaan media memanfaatkan kehadirannya dalam memproduksi dan menyebarkan informasi, salah satu medianya adalah mediaindonesia.com. Tujuan dari penelitian ini adalah untuk mengetahui bagaimana Media Indonesia membingkai pemberitaan tentang aksi gerakan \#2019gantipresiden pada edisi September 2018-Januari 2019. Penelitian ini menggunakan analisis framing Robert N. Entman dengan metode penelitian kualitatif dan paradigma konstruktivisme. Hasil penelitian ini menunjukkan bahwa mediaindonesia.com memiliki pandangan yang cenderung netral dan objektif. Informasi yang ditunjukkan dalam penelitian ini adalah adanya nilai yang dibawa dalam berita tentang \#2019gantipresiden adalah gerakan yang menimbulkan suatu perpecahan masyarakat yang memiliki perbedaan pendukung dalam kompetisi pemilu 2019. \#2019gantipresiden juga membawa nilai yang buruk bagi pemimpin yang sedang menjabat, karena dari nama dan berita yang ditonjolkan aksi tersebut condong kepada upaya menjatuhkan kepemimpinan Presiden.
\end{abstract}

Kata kunci: Analisis Framing, Robert N. Entman, \#2019gantipresiden, Media Online 


\section{Latar Belakang Permasalahan}

Di era perkembangan teknologi internet saat ini mempengaruhi kegiatan jurnalistik. Perkembangan tersebut ditandai oleh adanya manfaat media massa yang dapat memberikan dan membuat segala informasi. Menurut wahyudi media massa adalah sarana untuk menyampaikan pesan, pernyataan, informasi yang bersifat umum, kepada sejumlah orang yang relatif berjumlah besar, tempat tinggal yang beragam, heterogen, anonim, tidak terikat dengan lembaga, perhatiannya terpusat pada pesan yang sama, yaitu pesan media massa yang sama, dan tidak dapat memberikan feedback secara langsung pada saat pesan tersebar melalui media massa (Vera: 2016). Menurut Grolier (Putra: 2011), ada empat kategori besar media massa diantaranya adalah; (1) Media cetak, seperti koran, majalah, dan buku, (2) Media rekaman, berupa kaset audio dan kaset video, (3) Media film, dan (4) Media siar, seperti televisi dan radio. Kelebihan dari media massa adalah dapat mengatasi hambatan ruang dan waktu, media massa juga mampu untuk menyebarkan pesan secara cepat pada waktu yang tidak terbatas kepada khalayak (Nurudin, 2014: 9) Media online merupakan media yang didasari oleh perkembangan teknologi informasi dan internet yang dapat diakses melalui komputer. Beberapa kategori dalam media online adalah media sosial, streaming $T V$, streaming radio, portal berita online, email, dan lainnya (Muhtadi, 2016: 78)

Kegiatan jurnalistik online di Indonesia saat ini muncul sebagai media massa yang berfungsi sebagai sumber pencarian informasi yang cepat dan mudah diakses. Dari kelebihan jurnalistik online sangat membantu masyarakat dalam mendapatkan segala informasi dengan cepat. Dengan kehadiran internet, informasi tidak hanya disebarkan melalui media online yang disajikan dalam portal portal berita seperti detik.com, mediaindonesia.com, kompas.com, dan masih banyak lagi. Kini penyebaran informasi juga didukung melalui media interaksi yang sifatnya dapat memberikan feedback secara langsung, yaitu media sosial.

Kehadiran media sosial sangat mempengaruhi kegiatan jurnalistik seperti data pendukung untuk mendobrak informasi menjadi sebuah trend yang sedang diperbincangkan. Beberapa media sosial yang memiliki fitur pencarian trending topic adalah twitter, youtube, dan Instagram. Penggunaan media sosial memiliki sisi positif dan negatif. Bentuk positif dalam media sosial adalah bertambahnya pengetahuan yang disebarkan dalam media sosial. Adapun bentuk negatifnya adalah adanya kabar- 
kabar yang belum akurat untuk diyakini kebenarannya.

Pada tahun 2018 tepatnya sebelum pemilu 2019 diadakan, beberapa kelompok memanfaatkan media sosial sebagai sarana untuk menyebarkan informasi yang terkait dengan kampanye salah satu pasangan calon yang diunggulkan untuk memenangkan kompetisi dalam pemilu 2019 mendatang. Peneliti menemukan sejumlah data pencarian trending topic terkait kampanye yang disebarkan melalui instagram sejumlah 1.155 .611 post. Kampanye yang diramaikan dalam sejumlah media sosial dinamakan gerakan \#2019gantipresiden. Dengan adanya fitur hashtag dalam media sosial, gerakan tersebut menjadi sebuah kata kunci atau topik yang memungkinkan untuk diikuti oleh para pengguna media sosial. Tagar 2019 ganti Presiden juga sempat menjadi trending topic dalam twitter, bahkan sempat memuncaki tangga popularitas pada tanggal 9-10 April 2018 (Gunawan, 2018).

Aksi tagar 2019 ganti presiden pertama kali digagas oleh ketua DPP PKS Mardani Ali Sera pada bulan februari 2018, Pembentukan gerakan \#2019GantiPresiden berawal saat Mardani diundang acara debat di salah satu stasiun TV swasta. Mardani Ali Sera adalah politikus Partai Keadilan Sejahtera yang diketahui telah menjadi ketua tim pemenangan Anies-Sandiaga pada saat Pilgub DKI Jakarta 2017. Berkat keberhasilannya dalam kemenangan pasangan Anies-Sandiaga Uno, Mardani Ali Sera kembali dipercaya sebagai salah satu anggota tim kemenangan PrabowoSandiaga di ajang Pemilu 2019 mendatang. Menurutnya gerakan tersebut dibentuk untuk mendidik masyarakat dalam berpolitik, gerakan ini akan menimbulkan sebuah data analisa untuk mengenalkan calon yang lebih baik agar dipilih pada pemilu 2019.

Adanya pemberitaan tentang aksi gerakan \#2019gantipresiden yang diberitakan di banyak media, khususnya dalam media online merupakan suatu momentum penting dalam rangkaian acara pemilu 2019 mendatang. Setiap lawan politik memiliki caranya masing-masing pada saat kampanye dimulai. \#2019gantipresiden merupakan senjata teknologi baru untuk melawan kubu pasangan calon Jokowi-Ma'ruf. Dalam media, penelitian berita selalu dikaitkan dengan konstruksi dan realitas. Berita yang dibuat dalam media adalah makna yang ditafsirkan seorang wartawan pada suatu pesan (Eriyanto, 2012).

Berbagai media online yang memberitakan tentang aksi gerakan \#2019gantipresiden. Di Indonesia 
kepemilikan media memiliki latar belakang tokoh politik yang memiliki peran dalam memberitakan aksi gerakan \#2019gantipresiden, salah satunya adalah mediaindonesia.com. Portal berita tersebut memiliki peran penting dalam membentuk opini publik tentang aksi gerakan \#2019gantipresiden. Dimana kepemilikan mediaindonesia.com dipegang oleh salah satu tim pemenangan Jokowi-Ma'ruf di ajang pemilu pada bulan April 2019, yaitu Ketua Umum Partai Nasional Demokrat, Surya Paloh. Dari bentuk kepemilikan media serta kepentingannya, media berupaya untuk membangun suatu wacana tentang aksi gerakan 2019 ganti presiden. Atas dasar kepemilikan media yang dikaitkan dengan kegiatan pemilu 2019, peneliti menentukan mediaindonesia.com sebagai media yang diteliti, untuk melihat bagaimana pesan yang ditonjolkan oleh media yang latar belakang dan kepemilikan media merupakan salah satu pendukung dari pasangan calon JokowiMa'ruf pada pemilu 2019 mendatang.

Dalam penelitian ini, paradigma yang digunakan untuk menjelaskan pemberitaan tentang aksi gerakan \#2019gantipresiden adalah paradigma konstruktivisme dengan analisis framing model Robert N. Entman. Karakteristik dari analisis framing yang paling menonjol dibanding analisis teks lainnya adalah dari pembentukan pesan dari teks, terutama bagaimana suatu pesan atau peristiwa dikonstruksi oleh media dan bagaimana seorang wartawan mengkontruksi dan menyajikan suatu pesan atau peristiwa kepada masyarakat pembaca (Mulyana:2012). Pada dasarnya media mendiskusikan tentang suatu masalah yang melibatkan tiga pihak, yaitu: wartawan, Sumber berita, dan khalayak (Eriyanto:2012). Dalam konsep framing media bukanlah saluran yang bebas karena setiap media menyajikan berita dengan konsep yeng berbeda-beda, hal ini dikarenakan latar belakang setiap media dalam menyajikan beritanya (Eriyanto:2012).

Alasan peneliti menggunakan analisis framing model Robert N. Entman adalah karena pandangan Entman tentang framing media mengarah pada pemahaman dan pemilihan fakta yang dilakukan oleh media. Media menafsirkan sebuah realitas atau peristiwa yang ada dengan memilih isu yang akan ditampilkan, serta menonjolkan realitas tertentu dalam setiap berita yang disampaikan media. Framing Entman tidak merinci secara retoris, namun lebih melihat kepada bagaimana sebuah peristiwa dipahami dan bagaimana pemilihan fakta dilakukan media, 
selanjutnya disajikan kepada khalayak (Eriyanto:2012).

Penelitian ini ingin mengetahui bagaimana pembingkaian berita dalam mediaindonesia.com mengenai pemberitaan tentang aksi gerakan \#2019gantipresiden pada periode September 2018-Januari 2019. Peneliti ingin melihat perkembangan dari berita aksi tagar \#2019gantipresiden yang diberitakan oleh mediaindonesia.com serta didasari oleh penonjolan isu yang dikaitkan dengan pasangan lawan Prabowo-Sandi, yaitu pasangan JokowiMa'ruf selama serangkaian pemilu 2019 berjalan pada September 2018-April 2019, serta adanya keterkaitan antara kepemilikan media dan partai politik yang dibingkai melalui mediaindonesia.com. Maka dari itu peneliti menentukan judul penelitian sebagai berikut, Pemberitaan Aksi Gerakan 2019 Ganti Presiden (Analisis Framing Robert N. Entman di Mediaindonesia.com pada periode September 2018-Januari 2019).

\section{Metode Penelitian}

Penelitian yang berjudul "pemberitaan aksi gerakan tagar 2019 ganti presiden" dengan analisis framing Robert N. Entman di mediaindonesia.com menggunakam metode penelitian kualitatif dengan pendekatan konstruktivis.
Konstruktivis adalah bagaimana menemukan peristiwa atau realitas tersebut dikonstruksi, dengan cara apa konstruksi itu dibentuk (Eriyanto: 2012). Konstruktivis memandang realitas yang dibingkai media bukanlah realitas yang sebenarnya, melainkan suatu realitas yang diciptakan oleh individeu. Dalam penelitian ini peneliti menganggap bahwa dalam suatu berita yang ditulis oleh wartawan bukan hasail murni dari suatu peristiwa, melainkan konstruksi dari realitas. Peneliti ingin mengetahui bagaimana media menciptakan suatu realitas melalui berita yang disampaikan dan disajikan kepada khalayak, yaitu tentang aksi gerakan \#2019gantipresiden yang diberitakan oleh mediaindonesia.com.

\section{Hasil Dan Pembahasan}

Pada bagian ini, peneliti akan menjabarkan mengenai hasil penelitian yang telah peneliti analisis melalui lima berita yang dianalisis dalam mediaindonesia.com. Adapun unit analisisnya adalah:

1. Define Problems, yaitu bagaimana suatu peristiwa dilihat, sebagai apa? Atau sebagai masalah apa?

2. Diagnose Causes, yaitu penyebab dari suatu permasalahan, atau siapa yang menyebabkan masalah 
3. Make Moral Judgement, yaitu nilai moral yang disajikan untuk menjelaskan masalah, dan nilai moral yang digunakan dalam melegitimasi pemberitaan atau melegitimasi suatu pemberitaan

4. Treatment Recommendation, yaitu dengan melihat bagaimana penyelesaian masalah yang ditawarkan dalam pemberitaan

Dalam penelitian ini, peneliti menganalisis 5 berita yang disajikan oleh mediaindonesia.com dengan judul:

1. Tagar \#2019GantiPresiden Gejala Makar (12 September 2018)

2. Ada Teriakan 2019 Ganti Presiden di dalam Gedung MPR (29 Oktober 2018)

3. Kasus Video Pramuka Teriak 2019 Ganti Presiden Diadukan ke Polisi (08 November 2018)

4. Teriakan 2019 Ganti Presiden di Reuni 212 Diduga Dimobilisasi (02 Desember 2018)

5. Tidak Laku, Deklarasi Relawan Ganti Presiden 2019 di Kepri Gagal (13 Januari 2019)

Dari kelima berita yang dianalisis, peneliti ingin melihat pembingkaian tentang aksi gerakan \#2019gantipresiden di mediaindonesia.com dengan menggunakan empat perangkat framing Entman yang dijabarkan sebagai berikut:
1. Judul Berita: Tagar \#2019gantipresiden Gejala Makar

Define Problems: Penggunaan dan penyebaran \#2019gantipresiden adalah gejala makar

Diagnose Cause: Munculnya penggunaan dan penyebaran \#2019gantipresiden sebelum masa kampanye

Make Moral Judgement: Aksi gerakan \#2019gantipresiden memiliki potensi timbulkan konflik dan perpecahan publik.

Treatment Recommendation: Negara harus memiliki antisipasi dalam menanggapi gerakan yang memicu konflik menjelang pemilu 2019

2. Judul Berita: Ada Teriakan 2019 Ganti Presiden di dalam Gedung MPR

Define Problems: Teriakan 2019 ganti presiden menggema di acara diskusi tentang korupsi

Diagnose Cause: Wakil Sekjen Gerindra Ferry Juliantono memulai teriakan 2019 ganti presiden diluar pembahasan diskusi tentang korupsi

Make Moral Judgement: Beberapa peserta diskusi mengajak forum untuk tidak membahas pilpres 
Treatment Recommendation: Beberapa peserta mencoba hentikan pembahasan pilpres dan ajakan kembali fokus pembahasan diskusi di pertemuan diskusi tentang korupsi

3. Judul Berita: Kasus Video Pramuka Teriak 2019 Ganti Presiden Diadukan ke Polisi

Define Problems: Eksploitasi anak-anak dibawah umur tentang kepentingan kampanye \#2019gantipresiden.

Diagnose Cause: Anak-anak dibawah umur diajak menyerukan yel-yel 2019 ganti Presiden

Make Moral Judgement: Melibatkan anak-anak dibawah umur kedalam politik merupakan pelanggaran terhadap perlindungan anak.

Treatment Recommendation: Ketua KPAI Susanto mengirimkan surat kepada bareskrim polri terkait video viral tentang anak-anak berteriak yel-yel 2019 ganti Presiden yang merupakan eksploitasi anak dibawah umur.

4. Judul Berita: Teriakan 2019 Ganti Presiden di Reuni 212 Diduga Dimobilisasi

Define Problems: Reuni 212 mengandung muatan politis.
Diagnose Cause: Statement dari pemimpin FPI Rizieq Shihab menggaungkan slogan 2019 ganti Presiden di dalam reuni 212

Make Moral Judgement: Reuni 212 seharusnya tidak membawa unsur politik.

Treatment

Recommendation:

Penyelenggara pemilu harus memperhatikan aturan pemilu dan menyikapi peristiwa teriakan 2019 ganti presiden di reuni akbar 212.

5. Judul Berita: Tidak Laku, Deklarasi Relawan 2019 Ganti Presiden di Kepri Gagal

Define Problems: Deklarasi gerakan massa \#2019ganti Presiden di Kepri gagal.

Diagnose Cause: Kekurangan peserta gerakan massa \#2019gantipresiden membuat deklarasi tersebut gagal.

Make Moral Judgement: Sikap kepolisian dan bawaslu dalam menyikapi aturan kampanye di pemilu 2019 membuat kurangnya peserta deklarasi 2019 ganti Presiden, hingga batal dilaksanakan

Treatment Recommendation:

Anggota kepolisian dan bawaslu berjaga untuk memastikan kegiatan 
deklarasi \#2019ganti presiden bukan bagian dari kampanye.

Dari keseluruhan berita tentang aksi gerakan \#2019gantipresiden di mediaindonesia.com, peneliti menggunakan empat perangkat analisis framing Entman untuk melihat bagaimana mediaindonesia membingkai pemberitaan tentang \#2019gantipresiden.

1. Berdasarkan define problems, mediaindonesia.com mengidentifikasi bahwa penolakan gerakan \#2019gantipresiden disebabkan karena beberapa hal. Mediaindonesia.com mengidentifikasi bahwa penggunaan dan penyebaran \#2019gantipresiden adalah gejala makar yang dikaitkan dengan fenomena yang diberitakan dalam lima berita yang dipilih oleh peneliti. Fenomena tersebut didapat dari adanya indikator makar yang disebutkan pada berita pertama, yaitu dengan pemanfaatan media sosial dan ruang publik. Pemanfaatan media sosial yang dilakukan adalah penyebaran aksi \#2019gantipresiden, Viralnya video posko-posko keberangkatan di reuni akbar 212 yang difasilitasi oleh partai pendukung. Selain melalui media sosial, aksi \#2019gantipresiden juga dimanfaatkan melalui gerakan massa diruang publik, mediaindonesia.com menonjolkan pemberitaan tentang reuni akbar 212 yang membawa muatan politis, serta adanya kegiatan deklarasi relawan \#2019gantipresiden di Tanjungpinang.

2. Berdasarkan diagnose causes, mediaindonesia.com membingkai bahwa fenomena aksi \#2019gantipresiden digerakkan oleh partai pendukung kubu oposisi serta adanya dukungan publik. Kedua hal tersebut didapatkan dalam berita tentang "ada teriakan 2019 ganti Presiden di dalam Gedung MPR", “teriakan 2019 ganti Presiden di reuni akbar 212 diduga dimobilisasi”.

3. Berdasarkan make moral judgement, mediaindonesia.com membingkai nilai moral yang dapat menjelaskan permasalahan. Sikap yang ditonjolkan dalam mediaindonesia.com terkait aksi \#2019gantipresiden adalah aksi \#2019gantipresiden memiliki potensi yang dapat memecah persatuan publik, diketahui dari munculnya tandingan tagar \#2019gantipresiden yaitu \#Jokowi2periode. Kemudian mediaindonesia.com membingkai berita tentang hak perlindungan anak, dimana anak dibawah umur lebih bisa menyikapi bagaimana berpolitik dengan baik, dan tidak terpengaruh dengan nilai-nilai yang buruk. 
4. Berdasarkan

treatment

recommendation, mediaindonesia penyelenggara pemilu serta dukungan pemerintah agar bisa menanggapi segala peristiwa yang bertentangan dengan aturan pemilu 2019.

Berdasarkan empat perangkat framing Entman dalam lima berita yang telah dianalisis, hasil yang ditemukan tentang aksi gerakan \#2019gantipresiden dalam mediaindonesia.com adalah memberitakan bentuk penolakan terhadap gerakan \#2019gantipresiden. Mediaindonesia.com tidak memaparkan adanya dukungan dari gerakan tersebut, hal itu terdapat dari berita (1) yaitu gerakan 2019 ganti Presiden adalah gejala makar, berita (2) tentang bentuk sikap yang seharusnya mencerminkan ethos kerja pemerintah dalam menyikapi permasalahan yang terjadi di Indonesia, bukan keluar dari topik pembahasan yang dibawa dengan sindiran pilpres 2019, jelas itu adalah bentuk keraguan terhadap Presiden yang sedang menjabat dan bahkan cenderung menjatuhkan kredibilitas sang pemimpin. Berita (3) yaitu pengaduan kasus eksploitasi anak dibawah umur dengan doktrin anti Jokowi yang viral dalam media sosial, berita (4) tentang reuni akbar 212 yang diduga membawa muatan politis, dengan tanda- tanda bahwa adanya partai pendukung yang memfasilitasi acara tersebut. Berita (5) tentang kegagalan deklarasi \#2019gantipresiden di Kepri gagal karena minimnya peserta. Peneliti melihat bahwa mediaindonesia.com menonjolkan reaksi tentang gerakan \#2019gantipresiden dalam kelima berita adalah gerakan tersebut adalah gerakan negatif yang membawa pesan untuk menurunkan citra Presiden yang sedang menjabat serta cenderung memiliki potensi perpecahan publik.

Menurut Entman pendekatan framing media merupakan suatu proses seleksi dari berbagai aspek realitas, sehingga bagian tertentu dari suatu peristiwa lebih menonjol dibandingkan dengan aspek lainnya. Entman juga menempatkan informasi-informasi yang khas sehingga sisi tertentu mendapatkan alokasi lebih besar dibanding sisi lain (Eriyanto, 2012). Seleksi isu merupakan aspek yang memiliki kaitan dengan pemilihan fakta yang kemudian diberitakan dalam media (Eriyanto, 2012).

Dalam melakukan konstruksi, mediaindonesia.com melakukan tiga tahapan yaitu eksternalisasi, objektivasi, dan tahapan internal. Eksternalisasi adalah sebuah proses bagaimana manusia mengekspresikan dirinya secara terus menerus. Dalam hal ini peneliti mengaitkan proses eksternalisasi 
dengan cara mediaindonesia.com mengkonstruksi berita yaitu ketika seorang wartawan memaknai berita tentang aksi \#2019gantipresiden sebagai masalah serius dan harus ditindaklanjuti oleh pihak yang berwenang, yaitu pemerintah. Maka mediaindonesia.com secara terus menerus memberitakan fenomena tersebut sehingga berita diberikan secara berkala agar membangun suatu kepercayaan publik tentang \#2019gantipresiden yang telah beredar, dan untuk mengetahui bagaimana perkembangan berita tersebut. Objektivasi adalah hasil yang telah dicapai dari kegiatan sebelumnya, yaitu eksternalisasi.

Dalam tahapan eksternalisasi, tahap berikutnya sudah memasuki suatu penilaian tersendiri bagi audience, sehingga mereka mulai menilai dan mengikuti perkembangan berita yang ditampilkan oleh mediaindonesia.com. Yang ketiga adalah proses internalisasi yaitu ketika wartawan menulis berita tentang \#2019gantipresiden yang kemudian khalayak dapat menyaring informasi mana yang diambil dan mana yang diabaikan.

Peneliti melihat bahwa proses pembingkaian berita yang dilakukan oleh mediaindonesia.com telah melakukan tiga tahapan konstruksi yaitu dimulai dari persiapan materi konstruksi, sebaran konstruksi, hingga tahapan konfirmasi
(Bungin:2010). Tahapan persiapan konstruksi yang dilakukan mediaindonesia.com adalah membawa unsur kepentingan umum, yang bertujuan untuk memberikan informasi kepada masyarakat. Tahapan kedua adalah persiapan materi konstruksi, berita tentang aksi tagar \#2019gantipresiden di mediaindonesia.com lebih menonjolkan tentang pemberitaan yang disiapkan mengandung urgensi kepentingan masyarakat dalam berpolitik ketimbang kepentingan partai politik. Mediaindonesia.com menjelaskan tentang dampak yang akan terjadi apabila \#2019gantipresiden berkembang ditengahtengah jalannya rangkaian acara pemilu adalah timbulnya perpecahan masyarakat.

Tahapan yang ketiga adalah tahapan sebaran konstruksi, dalam tahapan ini mediaindonesia.com mencoba untuk memperlihatkan bagaimana pandangan media tentang aksi gerakan \#2019gantipresiden. Tahapan yang terakhir adalah tahapan konfirmasi, dalam tahapan ini mediaindonesia.com berupaya untuk menciptakan satu pandangan yang bisa diterima oleh masyarakat tentang berita \#2019gantipresiden yang ditampilkan media itu sendiri. Peneliti menemukan suatu kesimpulan dari kelima berita yang dibingkai oleh mediaindonesia.com, yaitu nilai yang dibawa dalam berita tentang 
\#2019gantipresiden adalah gerakan yang menimbulkan suatu perpecahan masyarakat yang memiliki perbedaan pendukung dalam kompetisi pemilu 2019 serta membawa nilai yang buruk bagi pemimpin yang sedang menjabat, karena dari nama dan berita yang ditonjolkan aksi tersebut condong kepada upaya menjatuhkan kepemimpinan Presiden.

\section{Penutup}

Dari hasil penelitian dan pembahasan yang dilakukan tentang pembingkaian berita aksi gerakan \#2019gantipresiden di mediaindonesia.com maka diperoleh kesimpulan sebagai berikut:

1. Seleksi isu oleh mediaindonesia.com yaitu memberitakan tentang \#2019gantipresiden disebut sebagai makar. Gerakan tersebut cenderung menjatuhkan pemimpin Indonesia yang sedang menjabat. Penyebaran makar dilakukan melalui media sosial dan juga memanfaatkan gerakan massa diruang publik. Beberapa kasus diantaranya telah melibatkan anak dibawah umur yang seharusnya tidak dikaitkan dengan nilai-nilai buruk dalam menyikapi politik. Dari fenomena yang terjadi mediaindonesia.com memberitakan tentang keharusan pemerintah, pihak kepolisian, dan juga penyelenggara pemilu untuk memperhatikan perkembangan \#2019gantipresiden agar tidak menimbulkan keributan dan juga perpecahan publik.

2. Penonjolan aspek dalam mediaindonesia adalah adanya penyebutan kalimat yang berulangulang. Hal tersebut menandakan bahwa \#2019gantipresiden adalah satu permasalahan besar yang harus diperhatikan oleh Pemerintah dan juga penyelenggara Pemilu. Dalam berita \#2019gantipresiden di mediaindonesia.com, salah satu pendorong aksi tersebut berkembang adalah adanya partai pendukung yang membantu aksi \#2019gantipresiden berkembang. Diketahui dari beberapa permasalahan yang diberitakan dalam mediaindonesia.com. Reuni 212 yang dimobilisasi oleh partai pendukung, kasus viral video anak pramuka teriak 2019 ganti Presiden yang diadukan ke Polisi, tidak lakunya deklarasi relawan 2019 ganti Presiden di Tanjungpinang.

3. Sebagai portal berita online mediaindonesia.com melakukan konstruksi sosial dengan kepentingan umum, dimana penonjolan berita yang dilakukan oleh mediaindonesia.com bersikap netral dan tidak memihak. Sikap netral dan tidak memihak yang dimaksud adalah, dalam kelima berita 
yang telah dianalisis, peneliti melihat bahwa konstruksi berita yang dilakukan oleh mediaindonesia.com adalah tidak menonjolkan suatu dukungan pada pasangan calon manapun, melainkan mediaindonesia.com memberitakan tentang kedudukan \#2019gantipresiden dan dampak negatif dari kampanye tersebut bagi kesatuan masyarakat selama pemilu 2019 berlangsung.

\section{Daftar Pustaka}

Bungin, B. 2010. Penelitian Kualitatif, Komunikasi, Ekonomi, Kebijakan Publik, dan Ilmu Sosial lainnya. Jakarta: Kencana Prenada Media Group.

Eriyanto. 2012. Analisis Framing, Konstruksi, Ideologi, dan Politik Media. Yogyakarta: LKIS Group.

Fauzi, Akmal. 2018, Oktober 29. Ada Teriakan 2019 Ganti Presiden di dalam Gedung MPR. Retrieved from https://mediaindonesia.com/read/deta il/194091 ada teriakan-2019-gantipresiden-di-dalam-gedung-mpr: https://mediaindonesia.com/read/deta il/194091-ada-teriakan-2019-gantipresiden-di-dalam-gedung-mpr

Fauzi, Akmal. 2018, November 08. Kasus Video Pramuka Teriak 2019 Ganti Presiden Diadukan ke Polisi. Retrieved from Media Indonesia: https://mediaindonesia.com/read/deta il/196559-kasus-video-pramukateriak-2019-ganti-presiden-diadukanke-polisi

Gunawan, B. 2018, April 30. Propaganda Politik Melalui 'Hashtag' Media
Sosial. Retrieved from Detik News: https://news.detik.com/kolom/39975 72/propaganda-politik-melaluihashtag-media-sosial

Jelita, I. N. 2018, Desember 02. Teriakan 2019 Ganti Presiden di Reuni 212 Diduga Dimobilisasi. Retrieved from Media Indonesia: https://mediaindonesia.com/read/deta il/201674-teriakan-2019-gantipresiden-di-reuni-212-didugadimobilisasi

Kremer, H. 2019, Januari 13. Tidak Laku, Deklarasi Relawan Ganti Presiden 2019 di Kepri Gagal. Retrieved from Media Indonesia: https://mediaindonesia.com/read/deta il/210231-tidak-laku-deklarasirelawan-ganti-presiden-2019-dikepri-gagal

Muhtadi, A. S. 2016. Pengantar Ilmu Jurnalistik. Bandung: Simbiosa Rekatama Media.

Mulyana, D. 2012. Analisis Framing. Yogyakarta: LKIS Group.

Nurudin. 2014. Pengantar Komunikasi Massa. Jakarta: PT Rajagrafindo Persada.

Octaviany, P. R. 2018, September 12. Tagar \#2019gantipresiden Gejala Makar. Retrieved from Media Indonesia:

https://mediaindonesia.com/read/deta il/184021-tagar-2019gantipresidengejala-makar

Putra, D. K. 2011. Hirarki Politik Media. In P. D. Arifin, Media dan Komunikasi Politik (pp. 213-232). Jakarta: Puskombis.

Vera, M. N. 2016. Komunikasi massa. Bogor: Ghalia Indonesia. 

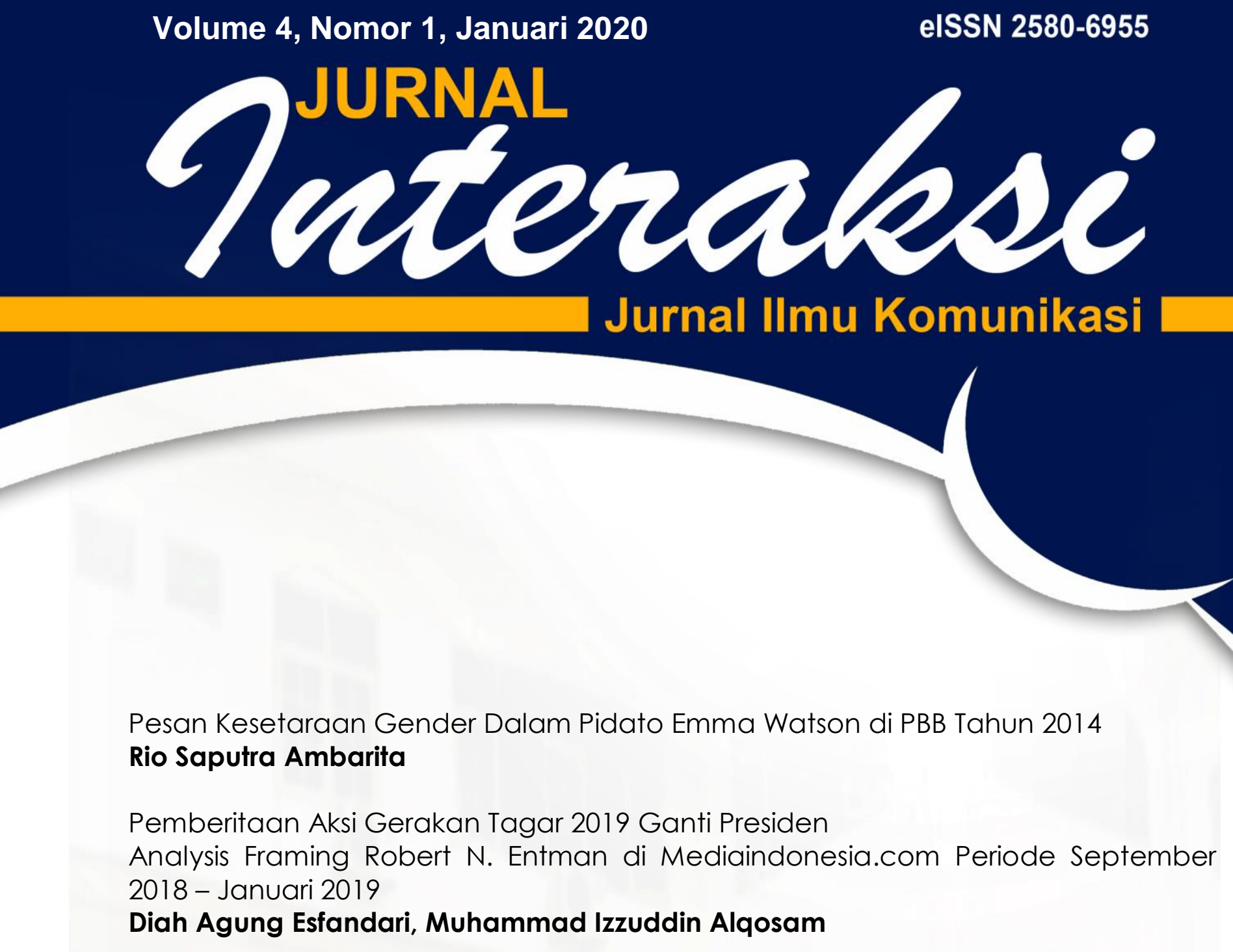

Branding Dan Positioning Identitas Budaya Indonesia Dalam Pesan Iklan TV Komersial Bejo Bintang Toedjoe Jahe Merah

Agus Hermanto, Sa'diah El Adawiyah

Identifikasi Faktor-Faktor Yang Mempengaruhi Minat Berkunjung Ke Olivier Café, Jakarta

\section{Tashia Tariq}

Studi Analisis Isi Pesan Dakwah Dalam Media Sosial Instagram @dakwah_tauhid Agus Triyono, Nifsya Khaira Marhuda

Relasi Politik, Bullying dan Etika Mengenai Isu "Muslim Uighur" di Media sosial Yofiendi Indah Indainanto

Breaking Down "Firewall" among Public Relations and Journalism Jamroji, Nasrullah

Strategi Komunikasi untuk Program Corporate Social Responsibility dalam Pemberdayaan Masyarakat

Arifin Saleh, Mislan Sihite 


\section{Turetralesi Jurnal IImu Komunikasi}

Jurnal Interaksi diterbitkan oleh Universitas Muhammadiyah Sumatera Utara (UMSU) bekerjasama dengan Asosiasi Pendidikan Ilmu Komunikasi Perguruan Tinggi Muhammadiyah (APIK PTM) yang terbit dua kali d alam setahun pada bulan Januari dan Juli. Terbit pertama kali pada bulan Januari 2017.

Jurnal Interaksi memuat tulisan yang difokuskan pada pemikiran kontemporer Ilmu Komunikasi, Media, Teknologi Komunikasi, Komunikasi Terapan, dalam berbagai sudut pandang atau perspektif. 


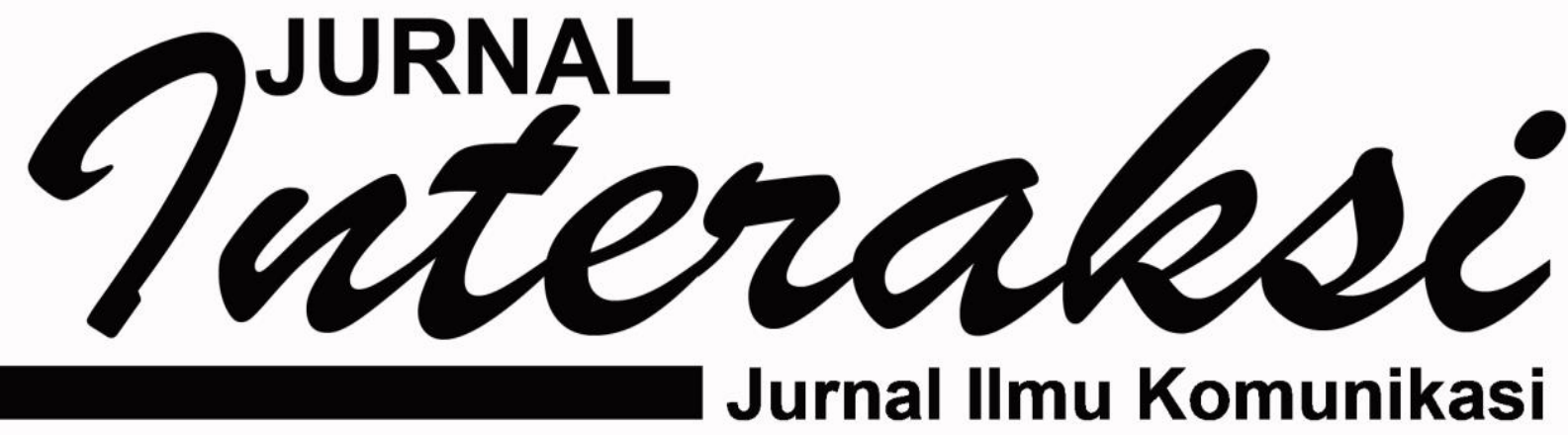

Pesan Kesetaraan Gender Dalam Pidato Emma Watson di PBB Tahun 2014 Rio Saputra Ambarita

Pemberitaan Aksi Gerakan Tagar 2019 Ganti Presiden

Analysis Framing Robert N. Entman di Mediaindonesia.com Periode September 2018 - Januari 2019

Diah Agung Esfandari, Muhammad Izzuddin Alqosam

Branding Dan Positioning Identitas Budaya Indonesia Dalam Pesan Iklan TV Komersial Bejo Bintang Toedjoe Jahe Merah

Agus Hermanto, Sa'diah El Adawiyah

Identifikasi Faktor-Faktor Yang Mempengaruhi Minat Berkunjung Ke Olivier Café, Jakarta

Tashia Tariq

Studi Analisis Isi Pesan Dakwah Dalam Media Sosial Instagram @dakwah_tauhid Agus Triyono, Nifsya Khaira Marhuda

Relasi Politik, Bullying dan Etika Mengenai Isu "Muslim Uighur" di Media sosial Yofiendi Indah Indainanto

Breaking Down "Firewall" among Public Relations and Journalism Jamroji, Nasrullah

Strategi Komunikasi untuk Program Corporate Social Responsibility dalam Pemberdayaan Masyarakat

Arifin Saleh, Mislan Sihite 


\section{Tuteralese}

Volume 4 Nomor 1 Edisi Januari 2020

\section{DAFTAR ISI}

\section{$1-11$}

Pesan Kesetaraan Gender Dalam Pidato Emma Watson di PBB Tahun 2014 Rio Saputra Ambarita

\section{$12-23$}

Pemberitaan Aksi Gerakan Tagar 2019 Ganti Presiden

Analysis Framing Robert N. Entman di Mediaindonesia.com Periode September 2018 - Januari 2019

\section{Diah Agung Esfandari, Muhammad Izzuddin Alqosam}

\section{4-40}

Branding Dan Positioning Identitas Budaya Indonesia Dalam Pesan Iklan TV Komersial Bejo Bintang Toedjoe Jahe Merah

Agus Hermanto, Sa'diah El Adawiyah

\section{1-49}

Identifikasi Faktor-Faktor Yang Mempengaruhi Minat Berkunjung Ke Olivier Café, Jakarta

\section{Tashia Taria}

\section{0-67}

Studi Analisis Isi Pesan Dakwah Dalam Media Sosial Instagram @dakwah_tauhid Agus Triyono, Nifsya Khaira Marhuda

\section{8-85}

Relasi Politik, Bullying dan Etika Mengenai Isu "Muslim Uighur" di Media sosial Yofiendi Indah Indainanto

\section{6-97}

Breaking Down "Firewall" among Public Relations and Journalism Jamroji, Nasrullah

98-105

Strategi Komunikasi untuk Program Corporate Social Responsibility dalam Pemberdayaan Masyarakat

Arifin Saleh, Mislan Sihite 